\title{
Detection of Rickettsia spp. in ticks (Acari: Ixodidae) of domestic animals in Colombia
}

\author{
Fredy A. Rivera-Páez ${ }^{\mathrm{a}, \mathrm{c}, *}$, Thiago F. Martins ${ }^{\mathrm{b}}$, Paula A. Ossa-López ${ }^{\mathrm{c}}$, Bruno Rodrigues Sampieri ${ }^{\mathrm{d}}$, \\ Maria I. Camargo-Mathias ${ }^{\mathrm{a}}$ \\ a Departamento de Biologia, Instituto de Biociências, UNESP - Universidade Estadual Paulista, Avenida 24-A, 1515, Bairro Bela Vista, Rio Claro, SP, CEP13506-900, \\ Brazil \\ ${ }^{\mathrm{b}}$ Departamento de Medicina Veterinária Preventiva e Saúde Animal, Faculdade de Medicina Veterinária e Zootecnia, Universidade de São Paulo, Av. Prof. Orlando \\ Marques de Paiva, 87, CEP 05508-000, Cidade Universitária, São Paulo, SP, Brazil \\ ${ }^{\mathrm{c}}$ Grupo de Investigación GEBIOME, Departamento de Ciencias Biológicas, Facultad de Ciencias Exactas y Naturales, Universidad de Caldas, Calle 65 No. 26-10 Apartado \\ Aéreo 275 Manizales, Caldas, Colombia \\ ${ }^{\mathrm{d}}$ Universidade Estadual de Campinas, Museu de Zoologia, R. Charles Darwin s/n, cidade universitária, Campinas, SP, Brazil
}

\section{A R T I C L E I N F O}

\section{Keywords:}

Candidatus Rickettsia andeanae

Endemic region

Rickettsia rickettsii.

\begin{abstract}
A B S T R A C T
Rickettsiosis are emerging or re-emerging diseases, with a worldwide distribution associated to transmission by arthropod vectors. Rickettsia species belong to the spotted fever group (SFG) and are transmitted by hard ticks (Acari: Ixodidae) that may act as vectors and reservoirs. This study carried out a molecular detection of Rickettsia from 7 species of the family Ixodidae collected from domestic hosts by PCR amplification of fragments of the citrate synthase "gltA" gene and outer membrane protein "ompA" gene. Of the 204 samples analyzed, 11.3\% (23) were positive for rickettsial infection. Three Rickettsia species belonging to the SFG were found, constituting the first reports of Rickettsia rickettsii in 2 departments of Colombia. Furthermore, we confirmed the first occurrence of Candidatus Rickettsia andeanae in Colombia, a species with an unknown pathogenic role in humans. These results raise awareness regarding the need to increase epidemiological control measures, as well as to consider new endemic regions in Colombia for Rocky Mountain spotted fever (RMSF).
\end{abstract}

\section{Introduction}

The genus Rickettsia encompasses strict intracellular bacteria that are transmitted by arthropods and mainly infect endothelial cells (Walker, 1982; Oteo et al., 2014). The genus is divided into four large groups: the typhus group (TG), the spotted fever group (SFG), the transitional group (TRG), and the ancestral group (AG) (Londoño et al., 2017). Rodents and ticks are the main reservoirs of Rickettsia; the initial infection of ticks with Rickettsiae can occur via the gut when bacteriafree ticks feed on rickettsemic hosts, or through transovarial or transstage transmission (Soares et al., 2012).

The first reported outbreak of tick-borne rickettsiosis in Colombia occurred between 1934 and 1936 in the municipality of Tobia, Department of Cundinamarca, and was named "Tobia spotted fever", which correspond to Rocky Mountain spotted fever (RMSF) caused by Rickettsia rickettsii. This disease affected $20 \%$ of the population and led to the death of 62 out of 65 patients (Patiño, 1941; Patiño et al., 1937). After a prolonged epidemiological silence, in 2003 and 2004, Hidalgo et al. (2007a) confirmed $R$. rickettsii as the causal agent of the death of two patients in the same region in Cundinamarca. Recently, three important SFG rickettsiosis outbreaks have occurred in Colombia, all caused by R. rickettsii: Necoclí - Department of Antioquia (2006), with five patients deceased out of 14 registered cases (Acosta et al., 2006); Los Córdobas - Department of Córdoba (2007), with 11 confirmed cases and the death of six patients (Hidalgo et al., 2007b), and Turbo - Antioquia (2008), with four patients deceased out of 15 reported cases (Pacheco et al., 2008).

Other important records for Colombia are: Faccini-Martínez et al. (2015) and Faccini-Martínez et al. (2016) isolated R. rickettsii and molecularly detected Rickettsia amblyommii from Amblyomma patinoi in the Department of Cundinamarca, and Londoño et al. (2014) registered specimens of Amblyomma ovale in the departments of Antioquia and Córdoba, infected by Rickettsia sp. strain Atlantic rainforest, which has shown to be pathogenic to humans. Gómez-Quintero et al. (2017) registered a probable case of a SFG rickettsial infection in a patient of the same region of the Colombian Orinoquía where Rivera-Páez et al.

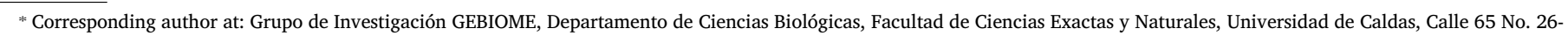
10 Apartado Aéreo 275 Manizales, Caldas, Colombia.

E-mail address: fredy.rivera@ucaldas.edu.co (F.A. Rivera-Páez). 
Table 1

Hard tick species and specimens analyzed - Detection and identification molecular of Rickettsia spp.

\begin{tabular}{|c|c|c|c|c|c|}
\hline State & Municipality & Host & $\begin{array}{l}\text { Tick species (number of specimens/ } \\
\text { stage) }\end{array}$ & $\begin{array}{l}\text { No. infected/No. } \\
\text { tested (\%) }\end{array}$ & $\begin{array}{l}\text { Closest GenBank identity (gene: accession } \\
\text { number) }\end{array}$ \\
\hline \multirow[t]{3}{*}{ Amazonas } & Leticia & Bos taurus & R. microplus (14/adults) & $0 / 14(0)$ & \\
\hline & & B. taurus - Equus caballus & D. nitens (4/adults) & $0 / 4(0)$ & \\
\hline & & Canis lupus familiaris & R. sanguineus s. 1. (6/adults) & $2 / 6(33.3)$ & $\begin{array}{l}\text { 100\% Candidatus } \text { R. andeanae [ompA: } \\
\text { KX158267] }\end{array}$ \\
\hline Antioquia & Medellín & C. lupus familiaris & R. sanguineus $\mathrm{s} .1$. (2/adults) & $0 / 2(0)$ & \\
\hline \multirow[t]{7}{*}{ Arauca } & Arauca & $\begin{array}{l}\text { E. caballus }- \text { B. Taurus - Sus } \\
\text { scrofa domesticus }\end{array}$ & D. nitens (15/adults) & $0 / 15(0)$ & \\
\hline & & E. caballus - B. taurus- & A. mixtum (23/adults) & $6 / 23(26.1)$ & $\begin{array}{l}\text { 100\% Rickettsia rickettsii [ompA: } \\
\text { KJ735645] }\end{array}$ \\
\hline & & E. caballus - C. lupus familiaris & R. sanguineus s. 1. (5/adults) & $0 / 5(0)$ & \\
\hline & & B. taurus & $R$ microplus (2/adults) & $0 / 2(0)$ & \\
\hline & Fortul & B. taurus & R. microplus (2/adults) & $0 / 2(0)$ & \\
\hline & Saravena & B. Taurus - C. lupus familiaris & R. microplus (3/adults; 2 nymps) & $0 / 5(0)$ & \\
\hline & & C. lupus familiaris & R. sanguineus $\mathrm{s} .1$. (2/adults) & $0 / 2(0)$ & \\
\hline \multirow[t]{2}{*}{ Bolívar } & San Jacinto & E. caballus- Equus asinus & D. nitens (4/adults) & $0 / 4(0)$ & \\
\hline & & E. asinus & R. microplus (1/adults) & $0 / 1(0)$ & \\
\hline \multirow[t]{3}{*}{ Caldas } & Dorada & C. lupus familiaris & R. sanguineus $\mathrm{s}$. 1. (2/adults) & $0 / 2(0)$ & \\
\hline & Neira & B. taurus & A. mixtum (5/adults) & $0 / 5(0)$ & \\
\hline & Norcasia & C. lupus familiaris & A. maculatum (2/adults) & $0 / 2(0)$ & \\
\hline \multirow[t]{7}{*}{ Casanare } & Nunchía & $\begin{array}{l}\text { E. caballus - B. taurus } \\
\text {-Vegetation }\end{array}$ & A. mixtum (12/adults) & $3 / 12(25)$ & $\begin{array}{l}\text { 100\% Rickettsia rickettsii [ompA: } \\
\text { KJ735645] }\end{array}$ \\
\hline & & E. caballus & D. nitens (2/adults) & $0 / 2(0)$ & \\
\hline & Yopal & C. lupus familiaris - E. caballus & R. sanguineus s. 1. (6/adults) & $0 / 6(0)$ & \\
\hline & & E. caballus & D. nitens (4/adults) & $0 / 4(0)$ & \\
\hline & & E. caballus - E. asinus & A. mixtum (10/adults) & $2 / 10(20)$ & $\begin{array}{l}\text { 100\% Rickettsia rickettsii [ompA: } \\
\text { KJ735645] }\end{array}$ \\
\hline & & Vegetation & A. mixtum (2/nymps) & $2 / 2(100)$ & $\begin{array}{l}\text { Rickettsia sp. strain Colombianensi } 100 \% \\
\text { [ompA: KF691749] }\end{array}$ \\
\hline & & Vegetation & A. dissimile (1/nymps) & $1 / 1(100)$ & $\begin{array}{l}\text { Rickettsia sp. strain Colombianensi 100\% } \\
\text { [ompA: KF691749] }\end{array}$ \\
\hline Cundinamarca & Puerto Salgar & C. lupus familiaris & R. sanguineus $\mathrm{s} .1$. (2/adults) & $0 / 2(0)$ & \\
\hline \multirow[t]{2}{*}{ Meta } & S. J. de Arama & B. taurus & A. mixtum (1/adults) & $0 / 1(0)$ & \\
\hline & & B. taurus & R. microplus (2/adults) & $0 / 2(0)$ & \\
\hline \multirow[t]{8}{*}{ Tolima } & Ibagué & B. taurus & R. microplus (7/adults) & $0 / 7(0)$ & \\
\hline & & B. taurus- C. lupus familiaris & R. sanguineus $\mathrm{s}$. 1. (12/adults) & $0 / 12(0)$ & \\
\hline & & C. lupus familiaris & A. maculatum (3/adults) & $3 / 3(100)$ & $\begin{array}{l}\text { 100\% Candidatus R. andeanae [ompA: } \\
\text { KX158267] }\end{array}$ \\
\hline & & C. lupus familiaris & A. ovale (8/adults) & $4 / 8(50)$ & $\begin{array}{l}\text { 100\% Candidatus R. andeanae [ompA: } \\
\text { KX158267] }\end{array}$ \\
\hline & & E. caballus - E. asinus & D. nitens (4/adults) & $0 / 4(0)$ & \\
\hline & Saldaña & C. lupus familiaris & R. sanguineus $\mathrm{s} .1$. (8/adults) & $0 / 8(0)$ & \\
\hline & & C. lupus familiaris & A. maculatum (14/adults) & $0 / 14(0)$ & \\
\hline & & C. lupus familiaris & A. ovale (2/adults) & $0 / 2(0)$ & \\
\hline \multirow[t]{4}{*}{ Valle del Cauca } & Cali & C. lupus familiaris & R. sanguineus s. 1. (2/adults; 3 nymps) & $0 / 5(0)$ & \\
\hline & Restrepo & C. lupus familiaris & R. sanguineus $\mathrm{s} .1$. (2/adults) & $0 / 2(0)$ & \\
\hline & & B. taurus & R. microplus (3/adults) & $0 / 3(0)$ & \\
\hline & & & $\begin{array}{l}\text { Total: } 204 \text { (196 adults: } 110 \text { males, } 86 \\
\text { females) and } 8 \text { nymphs. }\end{array}$ & $23 / 204(11.3)$ & \\
\hline
\end{tabular}

(2016) found the presence of Amblyomma mixtum, a vector of $R$. rickettsii.

Considering the medical importance of the different species of Rickettsia, the aim of this study was the molecular detection of Rickettsia species associated with hard ticks collected from domestic hosts in 10 departments of Colombia.

\section{Materials and methods}

From August 2014 to May 2016, hard ticks were collected from domestic hosts, including cattle (Bos taurus), domestic dogs (Canis lupus familiaris), horses (Equus caballus), donkeys (Equus asinus), and one domestic pig (Sus scrofa domesticus). In addition to two tick samples were collected from the vegetation, in farms from 17 municipalities of 10 departments of Colombia (Rivera-Páez et al., 2018). Collected ticks were placed into plastic vials containing absolute ethanol and taken to the laboratory, where they were taxonomically identified based on current literature (Kohls, 1956; Jones et al., 1972; Estrada-Peña et al., 2005; Barros-Battesti et al., 2006; Martins et al., 2010; Nava et al.,
2014, 2015). To confirm morphological identifications, some specimens of each tick species were subjected to molecular taxonomic identification by polymerase chain reaction (PCR) protocols to amplify fragments of at least one of the three following genes of the tick genome: targeting $\mathrm{a} \approx 700$-bp fragment of the mitochondrial cytochrome $\mathrm{c}$ oxidase subunit I gene (COI); targeting a $\approx 460$-bp fragment of the mitochondrial $16 \mathrm{~S}$ rDNA gene and $\mathrm{a} \approx 1100$-bp fragment that includes the entire second internal transcribed spacer (ITS2) region of the nuclear rRNA region (Rivera-Páez et al., 2018). Vouchers were deposited at the tick collection: "Coleção Nacional de Carrapatos Danilo Gonçalves Saraiva" - CNC (University of São Paulo, São Paulo, Brazil).

For the molecular detection and analysis of Rickettsia species, ticks were individually submitted to DNA extraction, using the DNeasy Blood and Tissue kit (Qiagen, Chatsworth, California), following the manufactureŕs protocol. Extracted DNA samples were tested by PCR, using primers CS-78 and CS-323, targeting a 401-bp fragment of the citrate synthase gene (gltA) for presumably all Rickettsia species (Labruna et al., 2004). To avoid false negatives, the positive and negative samples for gltA were further tested by another PCR protocol, 


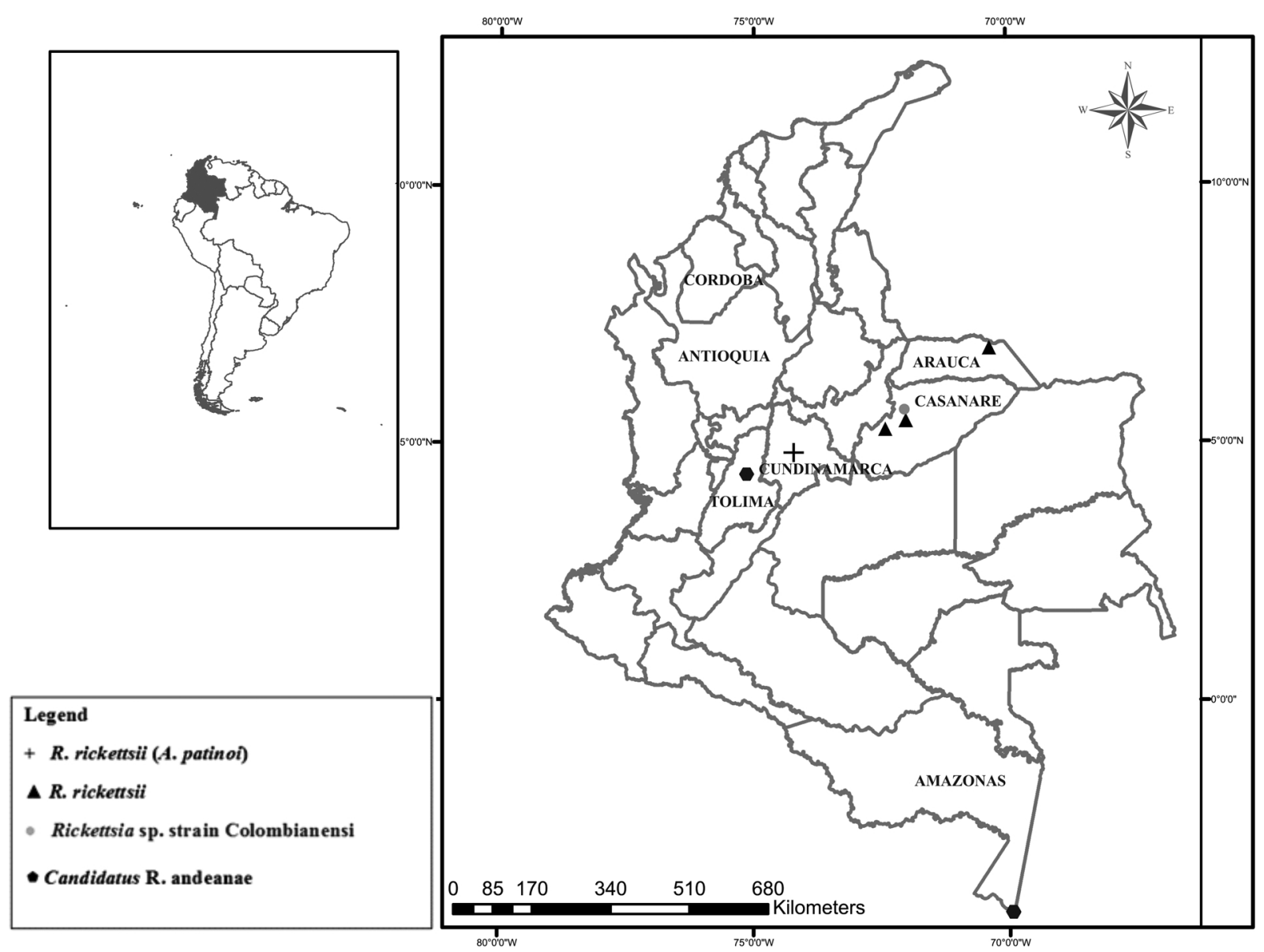

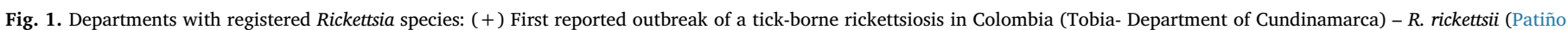

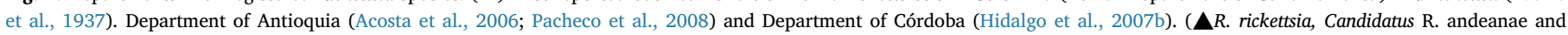
Rickettsia sp. strain Colombianensi) were reported during the present study.

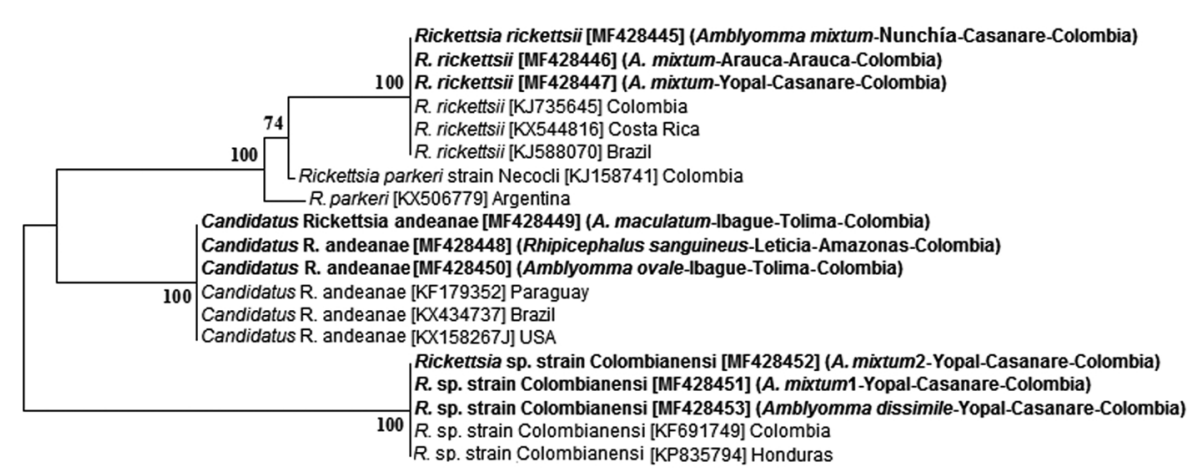

Fig. 2. Phylogenetic tree of Rickettsia species (detected in the present study in bold). Maximum Likelihood (ML) consensus tree using sequences of the 190-kDa outer membrane protein gene (ompA) present only in SFG Rickettsia species. Bootstrap values are only indicated for nodes with support greater than $70 \%$. The sequence of $R$. parkeri was used as outgroup. Analysis model was accomplished in the program MEGA 7 and intraspecific nucleotide divergences were estimated using the Kimura 2-Parameter distance model, with the program MEGA 7. using primers Rr190.70p and Rr190.602n, targeting a 530-bp fragment of the $190-\mathrm{kDa}$ outer membrane protein gene (ompA), present only in SFG Rickettsia species (Regnery et al., 1991). In each set of reactions, negative control tubes containing water and a positive control tube containing DNA of Rickettsia parkeri strain NOD were included.

PCR products were purified with the QIAquick PCR purification kit (Qiagen) and sent to the Universidad de Los Andes (Bogotá-Colombia) for DNA sequencing by the Sanger method. The gltA and ompA gene sequences were analyzed using Basic Local Alignment Search Tool (BLAST) (Altschul et al., 1990) to determine the closest similarities with other Rickettsia species. Species confirmation was carried out through a similarity analysis among gene ompA. Sequences obtained were evaluated and edited with the programs Geneious Trial v8.14 (Drummond et al., 2009). The sequences were search by MegaBlast against the public databases and to calculate sequence divergence, we downloaded sequences of closely related taxa available in GenBank database. Specifically, we obtained gene sequences corresponding to $R$. rickettsia, Candidatus Rickettsia andeanae and Rickettsia sp. strain Colombianensi; while, as outgroup, we used Rickettsia parkeri. The sequences were aligned using ClustalW (Thompson et al., 1997) included in the program MEGA version 7 (Tamura et al., 2013). Analysis model was accomplished in the program MEGA 7 (Tamura et al., 2013). Intraspecific nucleotide divergences were estimated using the Kimura 2-Parameter distance model (Kimura 2-parameter; Kimura, 1980), with the program MEGA 7. Species confirmation was carried out through a similarity analysis based on Maximum Likelihood (ML), with the K2P model and 
1000 bootstrap replications, using the program MEGA 7.

\section{Results}

204 ticks were obtained, belonging to seven species of the family Ixodidae. Of these 196 were adults (110 males, 86 females) and 8 nymphs (Table 1). Of the 204 samples analyzed, 11.3\% (23 ticks) were positive for rickettsial infection (Table 1). Three rickettsial agents were detected (Table 1, Fig. 1): i) $R$. rickettsii in A. mixtum (11 infected/ 53tested; $20.7 \%$ infection rate); ii) Candidatus Rickettsia andeanae in Rhipicephalus sanguineus sensu lato (2/52; $3.8 \%)$, A. ovale (4/10; 40\%) and A. maculatum $(3 / 19 ; 15.8 \%)$; and iii) Rickettsia sp. strain Colombianensi in A. mixtum (2/53; 3.8\%) and Amblyomma dissimile (1/1; $100 \%)$.

The partial gene sequences for gltA and ompA of $R$. rickettsii, Candidatus Rickettsia andeanae and Rickettsia sp. strain Colombianensi were both $100 \%$ identical to the corresponding sequences available for each species in GenBank (Table 1, Fig. 2). GenBank nucleotide sequence accession numbers for the partial sequences generated in the present study are [MF428454-MF428463] for the gltA gene, and [MF428445MF428453] for the ompA gene. This study demonstrated the presence of three SFG Rickettsia species based on PCR amplification of gltA and ompA gene fragments, in five municipalities of four departments of Colombia: $R$. rickettsii, in Arauca (Arauca), Yopal and Nunchía (Casanare); Candidatus R. andeanae, in Leticia (Amazonas) and Ibagué (Tolima); and Rickettsia sp. strain Colombianensi, in Yopal (Casanare).

\section{Discussion}

The new records of Rickettsia species in this work contribute to the knowledge of these infections in Colombia considering that only $R$. rickettsii has been the only species of the SFG identified in humans (Patiño et al., 1937). In addition, we found the presence of $R$. rickettsii in A. mixtum during active feeding on host, the second species of the Amblyomma cajennense complex recently registered for Colombia (Rivera-Páez et al., 2016) and a proven vector for $R$. rickettsii. Serological studies in human and animals conducted in the Colombian Orinoquía (departments of Arauca, Casanare, Guaviare, Meta, and Vichada) showed a high seroprevalence against SFGR (Miranda et al., 2011; Riveros-Pinilla et al., 2015) and, a probable case of infection by a Rickettsia species of the SFG (Gómez-Quintero et al., 2017). The molecular confirmation of $R$. rickettsii in three municipalities of the Orinoquía provides clear evidence that this region must be considered the third endemic region for rickettsiosis in Colombia, where only central (Department of Cundinamarca) and northwestern (Departments of Cordoba and Antioquia) regions of Colombia have constituted the two known endemic regions for rickettsiosis (Acosta et al., 2006; Hidalgo et al., 2007a, 2011).

Furthermore, the first record of Candidatus R. andeanae, in R. sanguineus s. 1. in Leticia (Amazonas of Colombia), as well as in A. ovale and A. maculatum in Ibagué (Tolima), were found. However, for being captured ticks during active feeding on host, it is necessary show by real-life transmission experiments which ticks to be a vector of Candidatus R. andeanae. This Rickettsia species has been registered in Brazil, Peru, Argentina, USA, Chile and Paraguay, and its role as a human pathogen is unknown (Ferrari et al., 2013; Witter et al., 2016). In any case, the study of this species is relevant, since Paddock et al. (2015) reported that a high prevalence of Candidatus R. andeanae leads presumably to the exclusion of $R$. parkeri in adult $A$. maculatum in Kansas and Oklahoma (USA), an event that could be occurring in the populations of $A$. maculatum analyzed herein, where all ticks studied were adults.

Similarly, Rickettsia sp. strain Colombianensi was typed by Miranda et al. (2012), in A. dissimile ticks collected from iguanas, and also Rhipicephalus microplus from vegetation in Montería (Colombia); however, there has been no evidence suggesting that this Rickettsia species is transmissible to humans (Miranda and Mattar, 2014). The first records of Rickettsia sp. strain Colombianensi for the species A. mixtum, as well as the infection for A. dissimile in the department of Casanare raise the need for studies addressing the possible pathogenic potential of this Rickettsia species and to show by real-life transmission experiments which ticks to be a vector of Rickettsia sp. strain Colombianensi.

\section{Acknowledgments}

To the AUIP-Asociación Universitaria Iberoamericana de Postgrado, CNPq-Conselho Nacional de Desenvolvimento Científico e Tecnológico, Unidad Administrativa Especial de Salud de Arauca-Programa ETV Gobernación de Arauca (Colombia). The project was funded by Vicerrectoría de Investigaciones y Posgrados - Universidad de Caldas (0180617).

\section{References}

Acosta, J., Díaz, A., Urquijo, L., Rey, G., Sepúlveda, C., Herrera, D., Zuluaga, W., 2006. Brote de Rickettsia rickettsii en Necoclí Antioquia, Colombia. Inf. Quinc. Epidemiol. Nac. 11, 161-176.

Altschul, S.F., Gish, W., Miller, W., Myers, E.W., Lipman, D.J., 1990. Basic local alignment search tool. J. Mol. Biol. 215, 403-410.

Barros-Battesti, D.M., Arzua, M., Bechara, G.H., 2006. Carrapatos de importância médico veterinária da Região Neotropical: um guia ilustrado para identificação de espécies, first ed. Vox/ICTTD-3/Butantan, São Paulo.

Drummond, A.J., Ashton, B., Cheung, M., Heled, J., Kearse, M., Moir, R., Stones, H.S., Thierer, T., Wilson, A., 2009. Geneious v.8.14. http://www.geneious.com (Accessed 13 February 2017).

Estrada-Peña, A., Venzal, J.M., Mangold, A.J., Cafrune, M.M., Guglielmone, A.A., 2005 The Amblyomma maculatum Koch, 1844 (Acari Ixodidae Amblyomminae) tick group: diagnostic characters, description of the larva of A. parvitarsum Neumann, 1901, 16S rDNA sequences, distribution and hosts. Syst. Parasitol. 60, 99-112.

Faccini-Martínez, Á.A., Costa, F.B., Hayama-Ueno, T.E., Ramírez-Hernández, A., CortésVecino, J.A., Labruna, M.B., Hidalgo, M., 2015. Rickettsia rickettsii in Amblyomma patinoi ticks, Colombia. Emerg. Infect. Dis. 21, 537-539.

Faccini-Martínez, Á.A., Ramírez-Hernández, A., Forero-Becerra, E., Cortés-Vecino, J.A., Escandón, P., Rodas, J.D., Palomar, A.M., Portillo, A., Oteo, J.A., Hidalgo, M., 2016. Molecular evidence of different Rickettsia species in Villeta, Colombia. Vector Borne Zoonotic Dis. 16, 85-87.

Ferrari, F.A., Goddard, J., Moraru, G.M., Smith, W.E., Varela-Stokes, A.S., 2013. Isolation of 'Candidatus Rickettsia andeanae' (Rickettsiales: Rickettsiaceae) in embryonic cells of naturally infected Amblyomma maculatum (Ixodida:Ixodidae). J. Med. Entomol. 50, 1118-1125.

Gómez-Quintero, C.H., Faccini-Martínez, Á.A., Botero-García, C.A., Lozano, M., SánchezLerma, L., Miranda, J., Mattar, S., Hidalgo, M., 2017. Probable case of spotted fever group rickettsial infection in a new suspected endemic area, Colombia. J. Infect. Public Health 10, 353-356.

Hidalgo, M., Orejuela, L., Fuya, P., Carrillo, P., Hernandez, J., Parra, E., Keng, C., Small, M., Olano, J.P., Bouyer, D., Castaneda, E., Walker, D., Valbuena, G., 2007a. Rocky Mountain spotted fever, Colombia. Emerg. Infect. Dis. 13, 1058-1060.

Hidalgo, M., Lizarazo, D., Ovalle, M., Castañeda, E., Heredia, D., Zambrano, P., Mantilla, G., Parra, E., Vera, M., Porras, A., Gaines, A., Múnera, G., Carrillo, P., Orejuela, L.G., 2007b. Brote de rickettsiosis en Los Córdobas, departamento de Córdoba, febrero-marzo 2007. Inf. Quinc. Epidemiol. Nac. 12, 371.

Hidalgo, M., Miranda, J., Heredia, D., Zambrano, P., Vesga, J.F., Lizarazo, D., 2011 Outbreak of Rocky Mountains potted fever in Córdoba, Colombia. Mem. Inst. Oswaldo Cruz. 106, 117-118.

Jones, E.K., Clifford, C.M., Keirans, J.E., Kohls, G.M., 1972. The ticks of Venezuela (Acarina: Ixodoidea) with a key to the species of Amblyomma in the western hemisphere. Brigham Young Univ. Sci. Bull. Biol. Ser. 17, 1-40.

Kimura, M., 1980. A simple method for estimating evolutionary rate of base substitutions through comparative studies of nucleotide sequences. J. Mol. Evol. 16, 111-120.

Kohls, G.M., 1956. Concerning the identity of Amblyomma maculatum, A., tigrinum, A. triste, and A. ovatum of Koch, 1844. Proc. Entomol. Soc. Wash. 58, 143-147.

Labruna, M.B., Whitworth, T., Horta, M.C., Bouyer, D.H., McBride, J.W., Pinter, A., Popov, V., Gennari, S.M., Walker, D.H., 2004. Rickettsia species infecting Amblyomma cooperi ticks from an area in the state of São Paulo, Brazil, where Brazilian spotted fever is endemic. J. Clin. Microbiol. 42, 90-98.

Londoño, A.F., Díaz, F.J., Valbuena, G., Gazi, M., Labruna, M.B., Hidalgo, M., Mattar, S., Contreras, V., Rodas, J.D., 2014. Infection of Amblyomma ovale by Rickettsia sp. strain Atlantic rainforest, Colombia. Ticks Tick Borne Dis. 5, 672-675.

Londoño, A.F., Acevedo-Gutiérrez, L.Y., Marín, D., Contreras, V., Díaz, F.J., Valbuena, G., Labruna, M.B., Hidalgo, M., Arboleda, M., Mattar, S., Solari, S., Rodas, J.D., 2017. Human prevalence of the spotted fever group (SFG) rickettsiae inendemic zones of Northwestern Colombia. Ticks Tick Borne Dis. 8, 477-482.

Martins, T.F., Onofrio, V.C., Barros-Battesti, D.M., Labruna, M.B., 2010. Nymphs of the genus Amblyomma (Acari Ixodidae) of Brazil: descriptions, redescriptions, and identification key. Ticks Tick Borne Dis. 1, 75-99.

Miranda, J., Mattar, S., 2014. Molecular detection of Rickettsia bellii and Rickettsia sp. 
strain Colombianensi in ticks from Cordoba, Colombia. Ticks Tick Borne Dis. 5, 208-212.

Miranda, J.L., Sánchez, L., Amaya, K., Máttar, S., 2011. Primera prueba serolágica de Rickettsia sp. del grupo de la fiebre manchada en el departamento del Meta. Biomódica 31, 103-113.

Miranda, J., Portillo, A., Oteo, J.A., Mattar, S., 2012. Rickettsia sp. strain Colombianensi (Rickettsiales: Rickettsiaceae): a new proposed Rickettsia detected in Amblyomma dissimile (Acari: Ixodidae) from iguanas and free-living larvae ticks from vegetation. J. Med. Entomol. 49, 960-965.

Nava, S., Beati, L., Labruna, M.B., Cáceres, A.G., Mangold, A.J., Guglielmone, A.A., 2014. Reassessment of the taxonomic status of Amblyomma cajennense (Fabricius, 1787) with the description of three new species, Amblyomma tonelliae n. sp., Amblyomma interandinum n. sp. and Amblyomma patinoi n. sp., and reinstatement of Amblyomma mixtum Koch, 1844, and Amblyomma sculptum Berlese, (Ixodida: Ixodidae). Ticks Tick Borne Dis. 5, 252-276.

Nava, S., Estrada-Peña, A., Petney, T., Beati, L., Labruna, M.B., Szabó, M.P., Guglielmone, A.A., 2015. The taxonomic status of Rhipicephalus sanguineus (Latreille, 1806). Vet. Parasitol. 208, 2-8.

Oteo, J.A., Nava, S., de Sousa, R., Mattar, S., Venzal, J.M., Abarca, K., 2014. Guías Latinoamericanas de la RIICER para el diagnóstico de las rickettsiosis transmitidas por garrapatas. Rev. Chilena Infectol. 31, 54-65.

Pacheco, O., Giraldo, R., Martinez, M., Hidalgo, M., Galeano, A., Echeverri, I., Echevarria, L., Parra, E., Rey, G., 2008. Estudio de brote febril hemorrágico en el corregimiento de Alto de Mulatos - Distrito Especial Portuario de Turbo, Antioquia, enero de 2008. Inf. Quinc. Epidemiol. Nac. 13, 145-160.

Paddock, C.D., Denison, A.M., Dryden, M.W., Noden, B.H., Lash, R.R., Abdelghani, S.S., Evans, A.E., Kelly, A.R., Hecht, J.A., Karpathy, S.E., Ganta, R.R., Little, S.E., 2015. High prevalence of Candidatus Rickettsia andeanae and apparent exclusion of Rickettsia parkeri in adult Amblyomma maculatum (Acari: Ixodidae) from Kansas and Oklahoma. Ticks Tick Borne Dis. 6, 297-302.

Patiño, L., Afanador, A., Paul, J.H., 1937. A spotted fever in Tobia, Colombia. Am. J.
Trop. Med. 17, 639-653.

Patiño, L., 1941. Nuevas Observaciones Sobre Un Tercer Foco De Fiebre Petequial (Maculosa) En El Hemisferio Americano. Bol. Sanit. Panam. 20, 1112-1124.

Regnery, R.L., Spruill, C.L., Plikaytis, B.D., 1991. Genotypic identification of rickettsiae and estimation of intraspecies sequence divergence for portions of two rickettsial genes. J. Bacteriol. 173, 1576-1589.

Rivera-Páez, F.A., Labruna, M.B., Martins, T.F., Sampieri, B.R., Camargo-Mathias, M.I., 2016. Amblyomma mixtum Koch, 1844 (Acari: Ixodidae): first record confirmation in Colombia using morphological and molecular analyses. Ticks Tick Borne Dis. 7, 842-848.

Rivera-Páez, F.A., Labruna, M.B., Martins, T.F., Perez, J.E., Castaño-Villa, G.J., OssaLópez, P.A., Gil, C.A., Sampieri, B.R., Arica-Giraldo, H.J., Camargo-Mathias, M.I., 2018. Contributions to the knowledge of hard ticks (Acari: Ixodidae) in Colombia. Ticks Tick Borne Dis. 9, 57-66.

Riveros-Pinilla, D.A., Acevedo, L., Londoño, A.F., Góngora, A., 2015. Antibodies against spotted fever group Rickettsia sp.: in horses of the Colombian Orinoquia. Rev. MVZ Córdoba 20, 5004-5013.

Soares, J.F., Soares, H.S., Barbieri, A.M., Labruna, M.B., 2012. Experimental infection of the tick Amblyomma cajennense, Cayenne tick, with Rickettsia rickettsii, the agent of Rocky Mountain spotted fever. Med. Vet. Entomol. 26, 139-151.

Tamura, K., Stecher, G., Peterson, D., Filipski, A., Kumar, S., 2013. MEGA 6: molecular evolutionary genetics analysis version 6.0. Mol. Biol. Evol. 30, 2725-2729.

Thompson, J.D., Gibson, T.J., Plewniak, F., Jeanmougin, F., Higgins, D.G., 1997. The CLUSTAL X windows interface: flexible strategies for multiple sequence alignment aided by quality analysis tools. Nucleic Acids Res. 25, 4876-4882.

Walker, D.H., 1982. Rickettsial diseases: an update. Monogr. Pathol. 23, 188-204.

Witter, R., Martins, T.F., Campos, A.K., Melo, A.L., Corrêa, S.H., Morgado, T.O., Wolf, R.W., May-Júnior, J.A., Sinkoc, A.L., Strüssmann, C., Aguiar, D.M., Rossi, R.V., Semedo, T.B., Campos, Z., Desbiez, A.L., Labruna, M.B., Pacheco, R.C., 2016. Rickettsial infection in ticks (Acari: Ixodidae) of wild animals in midwestern Brazil. Ticks Tick Borne Dis. 7, 415-423. 